\title{
CONNECTING THE DOTS OF CUSTOMER-BASED BRAND EQUITY TO BRAND ENGAGEMENT: USING THE DISJOINT TWO STAGE APPROACH OF PLS-SEM
}

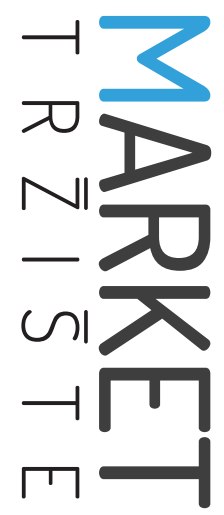

\section{POVEZANOST TRŽIŠNE VRIJEDNOSTI MARKE TEMELJENE NA PERCEPCIJI POTROŠAČA I ANGAŽMANA S MARKOM: KORIŠTENJE RAZDVOJENOG DVOSTUPANJSKOG PLS-SEM PRISTUPA}

\author{
Market-Tržište \\ Vol. 32, No. 2, 2020, pp. 147-168 \\ UDK 519.237:658.626:629.331(549) \\ DOl http://dx.doi.org/10.22598/mt/2020.32.2.147 \\ Original scientific paper
}

\begin{abstract}
Kashif Farhat ${ }^{\mathrm{a}}$, Sany Sanuri Mohd Mokhtar ${ }^{\mathrm{b}}$, Salniza Md. Salleh ${ }^{\mathrm{c}}$
a Universiti Utara Malaysia, School of Business Management, Sintok, 06010 Bukit Kayu Hitam, Kedah, MALAYSIA, e-mail: kashif. farhat@gmail.com

b Universiti Utara Malaysia, School of Business Management, Sintok, 06010 Bukit Kayu Hitam, Kedah, MALAYSIA, e-mail: sany@ uum.edu.my

c Universiti Utara Malaysia, School of Business Management, Sintok, 06010 Bukit Kayu Hitam, Kedah, MALAYSIA, e-mail: sal1029@uum.edu.my
\end{abstract}

\begin{abstract}
Purpose - The study aims to theoretically establish brand personality, brand experience, brand attributes, and brand affect as antecedents of brand engagement. Additionally, this study seeks to enhance customer-based brand equity and relationship marketing theories in relation to brand engagement behavior.
\end{abstract}

Design/methodology/approach - Through a survey questionnaire, 426 responses were collected from automobile customers. Following the multistage cluster sampling technique, respondents were contacted through the mall intercept method. The respondents' data was analyzed through PLS-SEM path modeling using the disjoint two-stage approach.

Findings and implications - Brand personality, brand experience, brand attributes, and brand affect sig-

\section{Sažetak}

Svrha - Cilj je rada teorijski utvrditi osobnost, doživljaj i osobine marke te naklonjenost marki kao prethodnice angažmana s markom. Dodatno, radom se nastoji poboljšati znanja o tržišnoj vrijednosti marke temeljenoj na percepciji potrošača i teorijama marketinga odnosa i suradnje povezanim s angažmanom s markom.

Metodološki pristup - Korištenjem anketnog upitnika prikupljeno je 426 odgovora od kupaca automobila. Slijedeći tehniku klasterskog uzorkovanja u više koraka, ispitanici su kontaktirani u trgovačkim centrima. Podaci dobiveni od ispitanika analizirani su korištenjem PLSSEM modeliranja strukturnih jednadžbi s razdvojenim dvostupanjskim pristupom.

Rezultati i implikacije - Osobnost, doživljaj i osobine marke te naklonjenost marki značajno objašnjavaju an- 
nificantly the brand engagement behavior being explained, especially, brand affect mediated between these antecedents and brand engagement.

Limitation - The cross-sectional research design of the study has some limitations. Further, brand affect, as a mediator, has explained $40.7 \%$ of the variation in brand engagement. Other mediators may explain the rest of the variation in brand engagement. As the study is related to the automobile market in Pakistan, the results may not be generalized to other parts of the world.

Originality - It is the first study to examine brand affect as a mediator that theoretically links brand personality, experience, attributes to brand engagement in an integrative framework, specifically for automobile brands. The disjoint two-stage approach of PLS-SEM in this study has been rarely used in marketing and business management research.

Keywords - brand engagement, brand experience, brand personality, brand attributes, automobile market of Pakistan, disjoint two-stage approach of PLS-SEM gažman s markom. Posebice, naklonjenost marki je medijator između prethodnica i angažmana s markom.

Ograničenja - Kros-selekcijski dizajn istraživanja ima određena ograničenja. Nadalje, naklonjenost marki kao medijator objašnjava $40,7 \%$ varijacije angažmana s markom. Drugi medijatori mogu objasniti ostatak varijacije angažmana s markom. Rezultati se ne mogu generalizirati s obzirom da je istraživanje povezano $s$ tržištem automobila u Pakistanu.

Doprinos - Ovo je prvi rad koji istražuje naklonjenost marki kao medijatora koji teorijski povezuje osobnost, doživljaj i osobine marki s angažmanom s markom u sveobuhvatni okvir, specifično za marke automobila. Razdvojeni dvostupanjski pristup u PLS-SEM-u rijetko je korišten u istraživanjima u marketingu i menadžmentu.

Ključne riječi - angažman s markom, doživljaj marke, osobnost marke, osobine marke, tržište automobila u Pakistanu, razdvojeni dvostupanjski pristup PLS-SEM-u 


\section{INTRODUCTION}

The dynamics of global automobile markets have changed over the years, with the power of manufacturing and demand shifting from the west to the east (Bernhart, Kleimann \& Hoffmann, 2011). This highlights the importance of marketing and customer-brand equity (CBBE) amidst the burgeoning competitive pressures in the Asian and global automobile markets (Adetunji, Rashid \& Ishak, 2018). The rising competition in the Asian automobile markets has caused the declining rate of customer retention due to customers' preferences for higher quality, superior brand experience, and the demand for automobile brands that augment self-image and distinctiveness of customers (Edmunds, 2018; Gerrits, Zhang, Klotz, Xu \& Xie, 2014). The shift in the customer preference calls for brand engagement strategies by automobile brands through superior brand experience since brand engagement manifests a long-term customer-brand relationship (Placing customer centercity, 2014; Skier, 2017). As the approach towards loyalty became increasingly ineffective, brand engagement emerged as a competitive strategy for businesses to gain a competitive edge (Chan, Zheng, Cheung, Lee \& Lee, 2014). Brand engagement is considered to be a better measure of long-term relationship and brand performance of products like automobiles that entail a high involvement of customers (Algesheimer, Dholokia \& Herrmann, 2005; Loureiro, Pires \& Kaufmann, 2015). Moreover, brand experience is the "new battlefield" for automobile brands (Skier, 2017) and the extant literature on brand engagement has few studies assessing the role of brand experience in creating brand engagement, especially in the context of automobile brands. Likewise, brand personality and brand affect are the essential factors for the purchase of high-involvement products like automobiles (The heart of the Issue, 2014; Punyatoya, 2011). But there is a sheer paucity of the studies investigating the antecedents of brand engagement in the environment of automobile brands, specifically if the brand equity drivers such as brand personality, brand experience, brand attributes, and brand affect create brand engagement behavior. Therefore, the primary objective of this research study is to examine if the foregoing brand equity drivers influence brand engagement of automobile brands. This study also responds to the earlier calls to determine the brand engagement antecedents such as brand personality (Lemon \& Verhoef, 2016) and brand affect (Bento, Martinez \& Martinez, 2018).

In addition, in the last decade, the automobile market in Pakistan has experienced a drastic shift. Customers who purchased the locally produced global brands, also known as semi-knocked down kits (SKDs) earlier, have demonstrated a persistent preference for reconditioned automobile brands (passenger cars) imported mostly from Japan and other Asian countries. It is believed that, at the core of the customers' preference for the reconditioned automobile brands, there lies customers' growing dissatisfaction with SKDs (Amir \& Asad, 2018) and the demand for superior brand experience and features like safety, style, and even image that imported reconditioned automobile brands offer (Mehmood, 2015; Zia \& Sohail, 2016). Consequently, in the last few years, the sales of the reconditioned automobile brands in Pakistan have soared swiftly. As recently as 2017, the sale of the reconditioned automobile brands was 65,000 units (Laghari, 2018), compared to 185,000 units of SKDs in the same year. The rapid growth in the preference for the imported reconditioned automobile brands caused the market share of SKDs to plunge to 73\% in 2018 from 92\% in 2011. The value of imported reconditioned automobiles in 2017 was around PKR 16 billion, reflecting the lost sales of the locally produced global brands in the country (Khan, 2017). In spite of various sources that emphasized the low customer perception of the SKDs in Pakistan and the falling loyalty towards SKDs (Abbas, 2018; Amir \& Asad, 2018; Khan, 2017; Mehmood, 2015), there is a serious gap of empirical knowledge to determine the potential factors that have caused the SKDs to

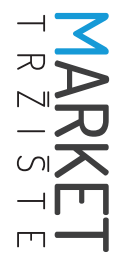


lose their market share to the imported reconditioned automobile brands.

Additionally, in Pakistan, the decision to purchase personal vehicles such as cars is driven by emotions (Farhat, Mokhtar \& Salleh, 2020a; Flop gear, 2015; Hanan, 2016) like in other parts of Asia (The heart of the Issue, 2014). Emotions act as a critical element for automobile customers in the country because personal vehicles have an impact on the social status (Agence France Presse [AFP], 2015) and depict the struggle of customers to purchase a personal vehicle (Flop gear, 2015). Hence, we assume that emotions are a critical driving force of automobile customers in Pakistan that influences their purchasing behavior. As the declining market share of SKDs and the rising preferences for imported reconditioned automobile brands have serious ramifications for the local automobile manufacturing and the economy, it is imperative to investigate this phenomenon from the marketing perspective.

The aim of this study is three-pronged: (1) to determine if brand experience, brand personality, brand attributes, and brand affect influence brand engagement of the SKDs; (2) to identify if brand affect (positive emotions) mediates the relationship between brand engagement and brand personality, brand experience, and brand attributes of the SKDs; and (3) to empirically link customer-based brand equity (CBBE) and relationship marketing theories to brand engagement. Due to the paucity of research in this context, this research study is guided by CBBE and relationship marketing theories. Importantly, the CBBE theory advocates for raising and leveraging brand perception that arises from positive brand experience, image, and feelings (Keller, 2003).

\section{THEORETICAL BACKGROUND}

Keller (2001) defined CBBE as the customers' preference for a brand that other competing brands attributed to the marketing efforts of the preferred brand. Keller (2001) extended CBBE by furnishing six building blocks: brand salience (identity), brand performance, brand imagery, brand judgments, brand feelings, and brand resonance. Whereas the first five blocks are essential to build CBBE, brand resonance reflects the CBBE that comprises brand engagement as the highest degree of loyalty (Farhat, Mokhtar \& Salleh, 2020b; Keller, 2016). Keller (2001, 2016) viewed brand engagement as customers' volunteer behaviors related to a brand manifested by investing their money, time, and other resources after the purchase and consumption process. Customers act as brand ambassadors and brand evangelists when they demonstrate brand engagement behavior. Brand engagement behavior has also been explored by the relationship marketing theory, which mainly stresses the long-term customer-brand relationship embodied in the interaction and exchanges between customers and brands (Vivek, Beatty \& Morgan, 2012). Like the CBBE, it emphasizes the importance of exploiting the resources of firms to inculcate brand loyalty (Yanfei \& Yafeng, 2012) as it will eventually trigger brand engagement behavior (Reichheld, 2003). In contrast, others believe that brand engagement measures the closely-knit relational bond between brands and customers, manifested through relational and repeated transactional exchanges (Sashi, 2012) and motivated by various stimulating factors (Ashley, Noble, Donthu \& Lemon, 2011). Keller $(2001,2016)$ also stated that brand engagement is the "in-sync" relationship between brands and customers, as a reflection of brand loyalty evoked by brand experience, personality, attributes, and brand affect (emotional response).

Despite a general lack of consensus over the definition of brand engagement among marketing scholar (Fernandes \& Esteves, 2016; Javornik \& Mandelli, 2012), several scholars have argued for the behavioral concept of brand engagement (Alloway \& Alloway, 2012; Calder, Malthouse \& Schaedel, 2009; van Doorn et al., 2010; Javornik \& Mandelli, 2012; Keller, 2001; Kumar et al. 2010; Pansari \& Kumar, 2017) rather 
than conceptualizing it as a cognitive, affective, and behavioral construct. The amalgamation of cognition, affect, and behavior in a single construct is a too broad approach and opposes the view that relational and emotional factors must precede in order for the brand engagement behavior to occur (Javornik \& Mandelli, 2012). Thus, we conceptualize brand engagement as a behavioral response of customers towards brands for the independent measurement of cognitive and affect constructs in the research framework, as suggested by Yoshida, Gordon, Nakazawa, Shibuya and Fujiwara, (2018). The behavioral concept of brand engagement is most practiced in marketing research studies (Fernandes \& Esteves, 2016; Yoshida et al., 2018) and is treated as a unidimensional construct (e.g. Brodie, Hollebeek, Jurić \& Ilić, 2011; Dessart, Veloutsou \& Thomas, 2015; Fernandes \& Esteves, 2016; Javornik \& Mandelli, 2012; Keller, 2001). Hence, we define brand engagement as a behavioral manifestation of customers to contribute money, energy, time, and other resources towards the brand beyond purchase and consumption, which comes as a direct result of motivational drivers and reflects enduring brand loyalty (Doorn et al., 2010; Keller, 2013).

Building upon the CBBE and relationship marketing theories, this study explores the contributing factors to brand engagement, especially those relevant to automobile brands in Pakistan. Figure 1 illustrates the research framework of the study and the related constructs, namely brand personality, brand experience, brand attributes, and brand affect as the antecedents of brand engagement. Brand affect is also a mediator in the relationship between brand engagement and brand personality, brand experience, and brand attributes. Likewise, earlier studies showed that brand personality, brand experience, and brand attributes significantly influence brand engagement through the mediating influence of brand affect (Candi, Makarem \& Mohan, 2017; Lee, Back \& Kim, 2009; Lyu, Mao \& $\mathrm{Hu}$, 2018). While Keller $(2001,2016)$ argued that brand affect (emotional responses) links the brand equity drivers such as brand personality, brand experience and brand attributes with brand engagement, Chaudhuri and Holbrook (2002) contended that brand affect is a vital construct for consumers to develop a relationship with brands. We define brand affect as the ability of a brand to trigger a positive emotional response in customers as a consequence of using a brand (Chaudhuri \& Holbrook, 2002). As an "emotional response measure", brand affect represents a comprehensive construct composed of various feelings that customers develop after consuming brands. Brand affect represents the feelings and emotions triggered by brands (Lin \& Lee, 2012), and many marketing researchers have also measured brand affect through brand passion (Füller, Matzler \& Hoppe, 2008), brand love (Albert \& Merunka, 2013), and affection (Halaszovich \& Nel, 2017) the marketing value of these artificial connections is questionable. This paper therefore aims to identify determinants of customers' intention to connect with a brand on social media (i.e. Facebook). Further, this study defines brand personality, brand experience, and brand attributes as cognitive antecedents of brand affect (emotions) that in turn influence brand engagement behavior. Therefore, the prime argument to base the framework of the study is that brand experience, brand personality, and brand attributes influence brand engagement as a result of the mediating role of brand affect, as proposed by earlier research (Franzak, Makarem \& Jae, 2014; Pansari \& Kumar, 2017). Brand affect is critical in the environment of automobile brands in Asian countries like Pakistan, where automobile purchase involves emotions (Nielsen Global, 2014; The heart of the Issue, 2014).

\subsection{Brand personality and brand affect}

Brand personality is defined as the human traits that a brand embodies (Keller, 2013) and as the human personality characteristics which are practical and relevant for brands (Azoulay \& Kapferer, 2003). Keller (2001) proposed brand

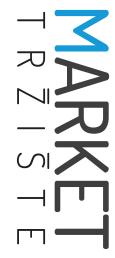


personality as an essential building block of the CBBE that triggers brand affect. Brand personality is also an important factor that influences the purchasing behavior of automobile brands (Brunello, 2015), and several studies in the past have investigated if brand personality evokes brand affect. A study by Kim and Zhao (2014) explored if brand personality predicted variation in evoking brand affect and eventually built loyalty behavior. They reported that brand personality is a significant predictor for brand affect. Sung and Kim (2010) also conducted a study to determine the dimensions that explained brand affect. The findings of their research established that brand personality significantly predicts brand affect. Therefore, we hypothesize that:

$\mathrm{H1}$ : Brand personality influences brand affect.

\subsection{Brand experience and brand affect}

Aaker (1991) claimed that the CBBE is a consequence of brand associations that ultimately form brand experience. Keller (2001) viewed brand experience as the unique personal experience derived from brands. However, a more comprehensive definition of brand experience is proposed by Brakus, Schmitt and Zarantonello (2009) as subjective, internal consumer responses as well as behavioral responses evoked by brand-related stimuli that are part of a brand's design, identity, packaging, communications, and environment. In their quest to find if brand experience evoked positive brand affect, Lyu and others (2018) contended that brand experience, especially the cognitive experience, is critical for arousing brand affect. Similarly, Huang (2017) hypothesized that brand experience predicts brand affect and furnished empirical evidence that behavioral, intellectual, and sensory experiences all influence brand affect. The significant influence of brand experience on brand affect was also reported by Pullman and Gross (2004), who established that experience influenced brand affect and finally formed customer loyalty. Along the same lines, Aslam, Ham, and
Farhat (2018) reported a significant influence of brand experience on brand affect. Based on the evidence from the literature, we hypothesize that:

H2: Brand experience influences brand affect.

\subsection{Brand attributes and brand affect}

The tangible and functional characteristics of products constitute brand attributes. Earlier literature, namely Keller (1993) and Lassar, Mittal and Sharma (1995)it is essential that any technique takes into account how the term brand is interpreted, since there are differing views about the meaning of 'brands'. This payer seeks to clarify the ways brands have been interpreted in the literature and, through a series of interviews with marketers, shows how brands are interpreted by marketing practitioners. A synthesis of the literature indicates five possible categories, i.e., brands as devices to show marketing control (ownership, posited that the functional elements of brands are the tangible attributes of brands. Brand performance is largely linked to brand attributes (Lassar et al., 1995; Pitta \& Katsanis, 1995) and a brand not meeting the performance expectations of customers is likely to have a lower degree of brand equity (Chieng \& Lee, 2011). We define brand attributes as the brand's physical composition of characteristics, such as functions, shape, style, design, and color (Sheng \& Teo, 2012), that indicate the nature and performance of brands (Song, Qin \& Yuan, 2019). Chitturi, Raghunathan and Mahajan (2007) predict that contexts involving functional versus hedonic trade-offs evoke a variety of both negative and positive emotions, including guilt/anxiety, sadness/disappointment, cheerfulness/excitement, and confidence/security. These predictions are confirmed. Furthermore, an analysis of the intensities of these specific emotions reveals the following additional insights: examined both functional and hedonic attributes of brands and whether these two types of attributes elicited brand affect (positive or negative). The 
findings demonstrated that the hedonic attributes of brands instigated negative brand affect while functional attributes explained positive brand affect. The brand attributes like packaging also have the potential to trigger brand affect (Liao, Corsi, Chrysochou \& Lockshin, 2015). Liao and others (2015) reported that even mock packaging, color and printed image evoke brand affect amongst customers. The design and features of automobile brands satisfy the visceral needs of customers, including the feelings attached to shape and color, and behavioral needs, the feelings linked with space and storage, and the reflective needs like retro, trendy, and futuristic design to make social statements (Helander, Khalid, Lim, Peng \& Yang, 2013). Attempting to leverage "animism" to the automobile brands, various features embodied in automobile brands activate emotional responses in customers towards automobile brands (Noble \& Kumar, 2010). Thus, we hypothesize that:

H3: Brand attributes influence brand affect.

\subsection{Brand affect and brand engagement}

Customers' emotions are an important part of consumer behavior (Holbrook \& Hirschman, 1982; Pham, 2004). Keller (2001) defined feelings as the emotional response of customers towards brands. In line with this, we define brand affect as the ability of brands to trigger a positive emotional response in customers related to the consumption of brands (Chaudhuri \& Holbrook, 2001). Hence, brand affect reflects the feelings or emotional response of customers towards a brand (Lin \& Lee, 2012) and is a prerequisite for brand engagement behavior, as proposed by Keller (2001). Samala and Singh (2019), for example, reported that Millennials who develop brand affect towards fashion brands are likely to demonstrate brand engagement. In the same vein, Xie, Batra and Peng (2015) found that brand affect is an antecedent and a mediator that predicts the brand engagement behavior of customers. Brand engagement behaviors such as feedback, positive WOM, helping and sharing information with other customers, and cooperation are triggered after customers develop affection towards a brand (Verleye, Gemmel \& Rangarajan, 2014). Therefore, we hypothesize that:

H4: Brand affect influences brand engagement.

\subsection{Mediation role of brand affect}

As brand affect measures the emotional response of customers related to consuming a brand, scholars state that emotions are at the core of customers' selection of product and services, post-purchase evaluation, resulting repurchase behavior, and the development of brand loyalty (Mattila \& Enz, 2002; Metrix, 2002). Brand affect mediates the relationships between brands-related stimuli and brand loyalty (Orzan, Platon, Stefanescue \& Orzan, 2016) while also mediating in the process of building brand equity (Sierra, Iglesias, Markovic \& Singh, 2015). Similarly, brand affect has been reported to have significant mediating power in previous marketing research studies (Bennur \& Jin, 2016; Khong \& Ong, 2014). The CBBE theory explains brand affect (emotional response) as a prerequisite to brand engagement behavior as well as a linking factor between brand equity drivers: brand personality, brand experience and brand attributes, and brand engagement (Keller, 2001, 2016).

The mediating role of brand affect in the relationship between brand personality and brand engagement is supported by past studies. Roy, Khandeparker and Motiani (2016) predicted that brand affect mediates between brand personality and brand engagement behavior; the data collected for online retailer brands endorsed the significant association of brand personality, sincerity, and excitement with brand engagement behavior (WOM) through the mediating influence of brand affect. Bairrada, Coelho and Lizanets (2018) sought to find if the personality of consumers brands explained brand affect (love) and ultimately resulted in brand engagement behavior. Their findings supported the

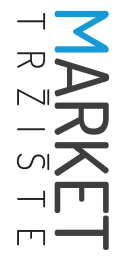




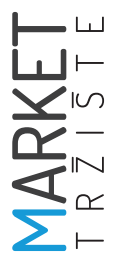

significant sequel relationship - brand personality to brand affect to brand engagement. Comparably, Matzler, Pichler and Hemetsberger (2007) have begun to witness a transition wherein firms are extending their focus beyond simply selling to business customers to serving them more effectively and in different ways. In order to accomplish this, many firms have developed e-business platforms to provide e-services to their buyers and business counterparts. With this in mind, this research examines the antecedents of e-business implementation in service firms, as well as the consequences associated with providing e-services to customers. Using the conceptual framework proposed by Javalgi et al. (2004) investigated if brand personality types such as openness and extraversion influenced brand engagement through the mediation of brand affect. Their findings confirmed that brand affect mediated this relationship. Thus, we posit that:

H5: Brand affect mediates in the relationship between brand personality and brand engagement.

Brand experience is said to be the new competitive arena for automobile brands (Skier, 2017). It fundamentally reflects the personal experience of customers and of their friends and relatives with a brand (Keller, 2001). The CBBE explains that brand experience influences brand engagement through the mediating power of brand affect. Previous studies, albeigt very few, have reported that brand experience elicits brand affect and, consequently, builds brand engagement. For example, brand affect provides a bridge between brand experience and brand engagement of the generation $M$ (Junaid, Hou, Hussain \& Kirmani, 2019). Likewise, environmental stimuli involving brand experience significantly evoke brand affect, followed by brand engagement (WOM) (Park \& Park, 2015). The mediation impact of brand affect between brand experience and brand engagement is not limited to products but also exists for services (Verleye et al., 2014). Therefore, we posit that:
H6: Brand affect mediates in the relationship between brand experience and brand engagement.

Brand attributes function as the primary source of judgment about the brand. The attributes include construction, physical attributes, and operational features of a product (Lassar et al., 1995). The attributes of various brands are the foundation of customer-based brand equity that help customers to identify the differentiating features and related benefits of brands. Brand attributes include both primary and secondary brand features that trigger brand affect in customers (Keller, 2001). Accordingly, favorable customer responses are largely the result of the tangible attributes of brands, such as design and packaging (Keller, 1993). Candi and others (2017) explored whether design and functional features of brands led to brand engagement behavior while mediated by brand affect. The data analysis supported the mediating effect of brand affect on the relationship between brand attributes and brand engagement behavior. Wakefield and Blodgett (1999) also reported brand affect as the mediating force between the tangible attributes of brands (décor and design) and brand engagement behavior. Thus, we hypothesize that:

$\mathrm{H}$ : Brand affect mediates in the relationship between brand attributes and brand engagement.

\section{METHODOLOGY}

\subsection{Instrument and measurements}

As marketing scholars lack a consensus on the types of feelings and emotions that constitute brand affect (Razzaq, Yousaf \& Hong, 2017), this study adapted the brand affect measurements conceptualized by Chaudhuri and Holbrook (2001) that constitute the feelings of excitement, fun, happiness, and enjoyment. Customers can experience a range of emotions (e.g. guilt, regret, pride, envy, joy, disappointment) but there is no single defining feature (concept) available in the literature to represent all emotions 
(Edwards, Jackson \& Pattison, 2002). Thus, the measurements of brand affect, adapted from Chaudhuri and Holbrook (2001) and Xie and others (2015), account for various positive emotional responses of customers and are widely adopted in marketing research. For brand personality, the measurements were adapted from Geuens, Weijters and De Wulf (2009); for brand experience, from Brakus and others (2009); for brand attributes, from Keller (2001) and Song and others (2019). The measurements for brand engagement were adapted from Bergkvist and bech-Larsen (2010).

A survey questionnaire was developed using a 5-point Likert scale for all constructs in the study. The questionnaire was pretested, and a pilot study was conducted as prescribed by Malhotra and Dash (2016). For the purpose of pretesting, three marketing experts assessed the questionnaire for appropriate wording, comprehension difficulty, instructions, sequence, and the layout of the questionnaire. A few alterations were made in the questionnaire and two items for brand personality were eliminated upon the recommendations of the marketing experts. The pilot study was conducted on 20 respondents who represented the target population of the study. This resulted in a few minor further adjustments in the questionnaire.

\subsection{Sample}

A sample consisting of automobile owners in Pakistan (passenger vehicles such as cars) was drawn using a multi-stage cluster sampling technique. Only the respondents who owned imported reconditioned car brands were selected for the sample. Out of the total of 2,889,500 registered passenger cars in the country until 2017-18, a sample of 538 responses was drawn, according to the guidelines by Krejcie and Morgan (1970) and Salkind (2012). The data was collected in three major cities of the country: Karachi, Lahore, and Islamabad. As per the cluster sampling guidelines of Sudman (1980), cities, shopping malls, and the entrance gates of the malls were selected for data collection. The mall intercept method was employed to contact respondents. Importantly, data collection through the mall intercept method following the guidelines of Sudman (1980) is similar to cluster sampling (Sudman \& Blair, 1999). The collected responses were further evaluated for invalid, incomplete responses, and for outliers; subsequently, the final data for analysis comprised 426 responses.

\section{RESULTS}

PLS-SEM modeling, a second-generation multivariate technique known for its effectiveness and adaptability in quantitative data analysis (Cheah et al., 2018), was used to analyze the respondents' data. A major advantage of PLSSEM is that it allows the measuring of hierarchical-component models (HCM), also referred to as second-order/higher-order constructs (Becker, Klein \& Wetzels, 2012; Ringle, Sarstedt \& Straub, 2012). This study also includes two second-order constructs: brand personality and brand experience, and PLS-SEM enables a simultaneous measurement of these two second-order constructs in a single framework. All constructs in this study are reflective.

In this study, brand personality and brand experience constructs have been measured as reflective second-order constructs as recommended by Aguilar, Guillén and Roman (2016) and Yasin, Porcu, Liébana-Cabanillas and Cabanillas (2019). Aguilar and others (2016) further argued that employing brand personality as a second-order construct provides a better fit of the model and a simpler explanation of its impact on other related constructs. Since the number of items is unequal in the two reflective-reflective second-order constructs, i.e. brand personality and brand experience, the disjoint two-stage approach of PLS-SEM has been used to assess the measurement model, as recommended by Sarstedt, Hair, Cheah, Becker and Ringle (2019).

The skewness and kurtosis values ranged between +3 and -3 , suggesting normality of the

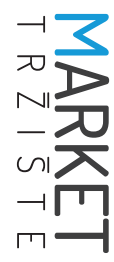


data (Kumar, Lee \& Kim, 2009). To assess the bias in the responses, Harman's single factor test was employed and showed a maximum variance below 50\%, indicating the absence of bias (Podsakoff \& Organ, 1986). The variance inflation factor (VIF) test used to examine multicollinearity displayed values between 1.98 and 2.90, suggesting multicollinearity lower than the threshold value of 5 (Hair, Sarstedt, Ringle \& Mena, 2011).

\subsection{Measurement model assessment}

The measurement model in PLS-SEM establishes the validity and reliability of constructs in a study (Ramayah, Chow \& Chyaw, 2011). For the disjoint two-stage approach, the measurement model assessment was conducted in two consecutive steps, referred to as $1^{\text {st }}$ stage and $2^{\text {nd }}$ stage measurement model in the current study. Outer loadings and composite reliability (CR) values were used to assess the reliability of items and constructs. For convergent validity, the average variance extract (AVE) was employed, and cross-loadings and the HTMT criterion for discriminant validity.

TABLE 1: Reliability and convergent values $-1^{\text {st }}$ and $2^{\text {nd }}$ stage measurement model

\begin{tabular}{|c|c|c|c|c|c|}
\hline $\begin{array}{l}\text { Lower-order } \\
\text { constructs }\end{array}$ & $\begin{array}{l}\text { Higher-order } \\
\text { constructs }\end{array}$ & Items & Loadings & AVE & CR \\
\hline \multirow{2}{*}{ Responsibility } & & PRSRSP1 & 0.842 & 0.751 & 0.858 \\
\hline & & PRSRSP2 & 0.891 & & \\
\hline \multirow[t]{3}{*}{ Activity } & & PRSACT3 & 0.795 & 0.635 & 0.839 \\
\hline & & PRSACT4 & 0.820 & & \\
\hline & & PRSACT5 & 0.774 & & \\
\hline \multirow[t]{2}{*}{ Aggressiveness } & & PRSAGG6 & 0.857 & 0.756 & 0.861 \\
\hline & & PRSAGG7 & 0.882 & & \\
\hline \multirow[t]{6}{*}{ Simplicity } & & PRSIMP8 & 0.830 & 0.632 & 0.774 \\
\hline & & PRSIMP9 & 0.759 & & \\
\hline & \multirow{4}{*}{ Brand personality } & Responsibility & 0.748 & 0.564 & 0.837 \\
\hline & & Activity & 0.824 & & \\
\hline & & Aggressiveness & 0.683 & & \\
\hline & & Simplicity & 0.742 & & \\
\hline \multirow[t]{3}{*}{ Sensory } & & EXPSNS1 & 0.859 & 0.722 & 0.886 \\
\hline & & EXPSNS2 & 0.865 & & \\
\hline & & EXPSNS3 & 0.824 & & \\
\hline \multirow[t]{4}{*}{ Cognitive } & & EXPCOGN4 & 0.770 & 0.582 & 0.848 \\
\hline & & EXPCOGN5 & 0.813 & & \\
\hline & & EXPCOGN6 & 0.746 & & \\
\hline & & EXPCOGN7 & 0.720 & & \\
\hline \multirow[t]{4}{*}{ Behavioral } & & EXPBHV8 & 0.793 & 0.620 & 0.867 \\
\hline & & EXPBHV9 & 0.744 & & \\
\hline & & EXPBHV10 & 0.822 & & \\
\hline & & EXPBHV11 & 0.788 & & \\
\hline
\end{tabular}


Table 1 - Continued

\begin{tabular}{|c|c|c|c|c|c|}
\hline $\begin{array}{l}\text { Lower-order } \\
\text { constructs }\end{array}$ & $\begin{array}{l}\text { Higher-order } \\
\text { constructs }\end{array}$ & Items & Loadings & AVE & CR \\
\hline & \multirow{3}{*}{ Brand experience } & Sensory & 0.858 & 0.688 & 0.868 \\
\hline & & Cognitive & 0.805 & & \\
\hline & & Behavioral & 0.824 & & \\
\hline \multirow[t]{4}{*}{ Brand affect } & & AFF1 & 0.751 & 0.631 & 0.895 \\
\hline & & AFF2 & 0.830 & & \\
\hline & & AFF3 & 0.777 & & \\
\hline & & AFF4 & 0.845 & & \\
\hline \multirow[t]{8}{*}{ Brand attributes } & & ATT1 & 0.768 & 0.576 & 0.905 \\
\hline & & ATT2 & 0.762 & & \\
\hline & & ATT3 & 0.742 & & \\
\hline & & ATT4 & 0.713 & & \\
\hline & & ATT5 & 0.807 & & \\
\hline & & ATT6 & 0.800 & & \\
\hline & & ATT7 & 0.714 & & \\
\hline & & AFF5 & 0.763 & & \\
\hline \multirow[t]{6}{*}{ Brand engagement } & & ENG1 & 0.693 & 0.532 & 0.872 \\
\hline & & ENG2 & 0.751 & & \\
\hline & & ENG3 & 0.699 & & \\
\hline & & ENG4 & 0.683 & & \\
\hline & & ENG5 & 0.783 & & \\
\hline & & ENG6 & 0.761 & & \\
\hline
\end{tabular}

Table 1 shows the assessment of the measurement models for the $1^{\text {st }}$ and the $2^{\text {nd }}$ stage. A common practice is to retain only those items that show loadings between 0.60 and 0.90 (Hair, Risher, Sarstedt \& Ringle, 2019). However, a more appropriate practice is to retain items with outer loadings $\geq 0.40$ if AVE values of a construct (involving all related items) are $\geq 0.50$ (Byrne, 2016). Thus, the items that contributed to AVE values $\geq 0.50$ were retained in the $1^{\text {st }}$ and the $2^{\text {nd }}$ stage of measurement models. The retained items in Table 1 demonstrate loadings $\geq 0.68$. Due to low outer loadings, three items were removed, namely PRSEMOT10 (emotion for brand personality), ATT2 and ATT8 (for brand attributes). For constructs reliability, CR values ranged between
0.774 and 0.905 , satisfying the minimum threshold recommended $\geq 0.70$ (Hair, Hult, Ringle \& Sarstedt, 2014). For convergent validity, the AVE values ranged between 0.564 and 0.756 . Table 2 and Table 3 display the HTMT criterion values for the $1^{\text {st }}$ stage and the $2^{\text {nd }}$ stage of measurement models for discriminant validity. As shown in table 2, HTMT values ranged between 0.296 and 0.827 for the $1^{\text {st }}$ stage of the measurement model. Likewise, HTMT values in Table 3 ranged between 0.670 and 0.896 for the $2^{\text {nd }}$ stage measurement model. Thus, HTMT values for both stages satisfy the discriminant validity $\leq 0.90$, as per guidelines provided by Gold, Malhotra and Segars (2001). Figure 1 and Figure 2 illustrate $1^{\text {st }}$ and $2^{\text {nd }}$ stage measurement models, respectively. 
TABLE 2: $1^{\text {st }}$ stage discriminant validity - HTMT criterion

\begin{tabular}{|c|l|c|c|c|c|c|c|c|c|c|c|}
\hline No. & Constructs & $\mathbf{1}$ & $\mathbf{2}$ & $\mathbf{3}$ & $\mathbf{4}$ & $\mathbf{5}$ & $\mathbf{6}$ & $\mathbf{7}$ & $\mathbf{8}$ & $\mathbf{9}$ & $\mathbf{1 0}$ \\
\hline 1 & Affect & & & & & & & & & & \\
\hline 2 & Attributes & 0.763 & & & & & & & & & \\
\hline 3 & Engagement & 0.760 & 0.604 & & & & & & & & \\
\hline 4 & Behavior & 0.806 & 0.696 & 0.616 & & & & & & & \\
\hline 5 & Cognition & 0.646 & 0.486 & 0.489 & 0.592 & & & & & & \\
\hline 6 & Sensory & 0.742 & 0.625 & 0.583 & 0.660 & 0.771 & & & & & \\
\hline 7 & Activity & 0.772 & 0.743 & 0.609 & 0.667 & 0.42 & 0.496 & & & & \\
\hline 8 & Responsibility & 0.602 & 0.526 & 0.483 & 0.442 & 0.232 & 0.373 & 0.707 & & & \\
\hline 9 & Aggressiveness & 0.562 & 0.551 & 0.526 & 0.605 & 0.364 & 0.417 & 0.614 & 0.473 & & \\
\hline 10 & Simplicity & 0.782 & 0.684 & 0.716 & 0.618 & 0.296 & 0.463 & 0.789 & 0.827 & 0.694 & \\
\hline
\end{tabular}

The cross-loadings of constructs were also test- all other constructs in the study (Hair et al., 2014). ed for discriminant validity. Cross-loading values of a construct are recommended to be larger Appendix A provides the cross-loading values within itself than its loadings corresponding to

FIGURE 1: $1^{\text {st }}$ stage measurement model

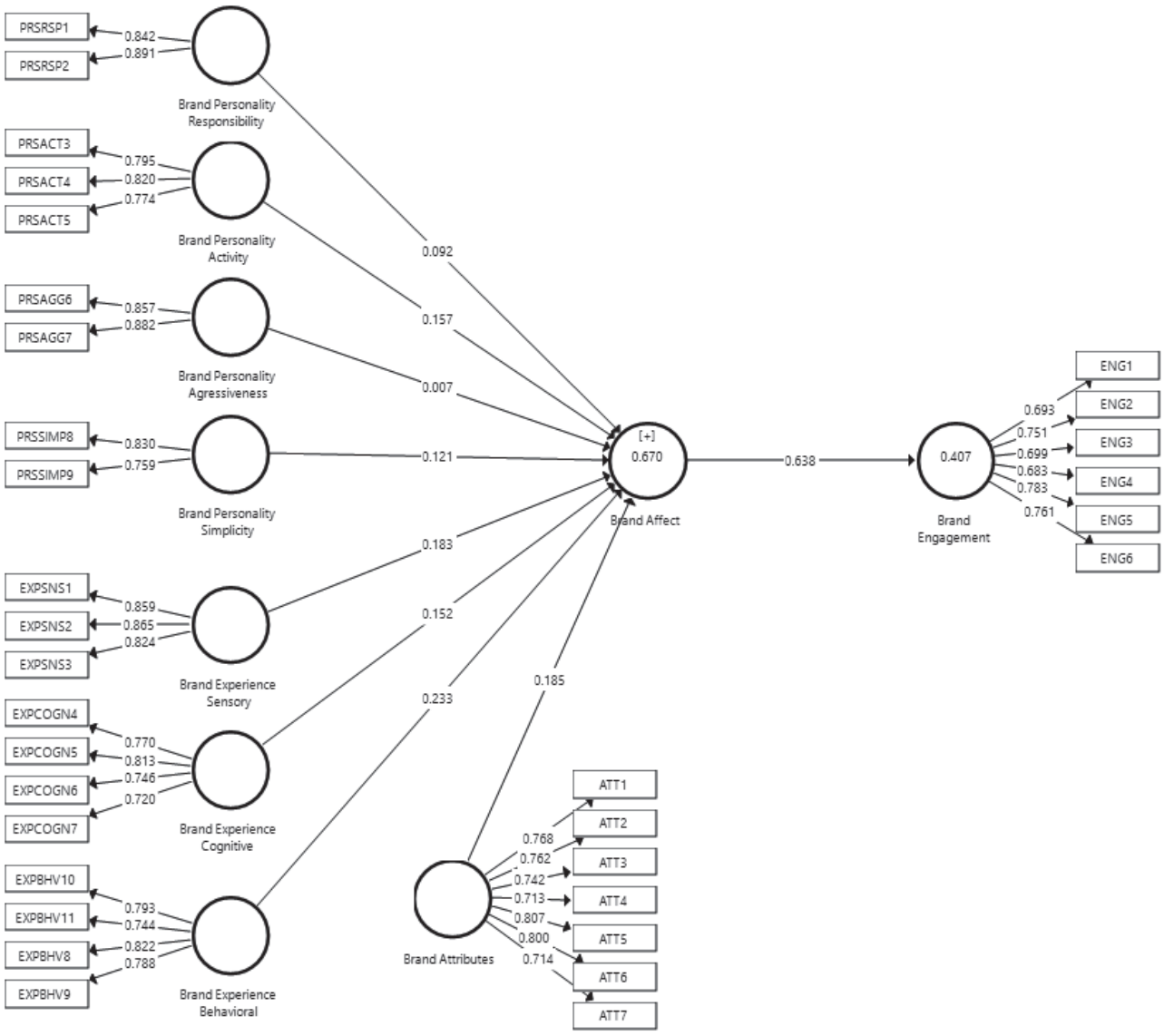


TABLE 3: $2^{\text {nd }}$ stage discriminant validity - HTMT criterion

\begin{tabular}{|c|l|c|c|c|c|c|}
\hline No. & \multicolumn{1}{|c|}{ Constructs } & $\mathbf{1}$ & $\mathbf{2}$ & $\mathbf{3}$ & $\mathbf{4}$ & $\mathbf{5}$ \\
\hline 1 & Affect & & & & & \\
\hline 2 & Attributes & 0.763 & & & & \\
\hline 3 & Experience & 0.896 & 0.737 & & & \\
\hline 4 & Personality & 0.821 & 0.759 & 0.670 & & \\
\hline 5 & Engagement & 0.760 & 0.604 & 0.690 & 0.702 & \\
\hline
\end{tabular}

FIGURE 2: $2^{\text {nd }}$ stage measurement model

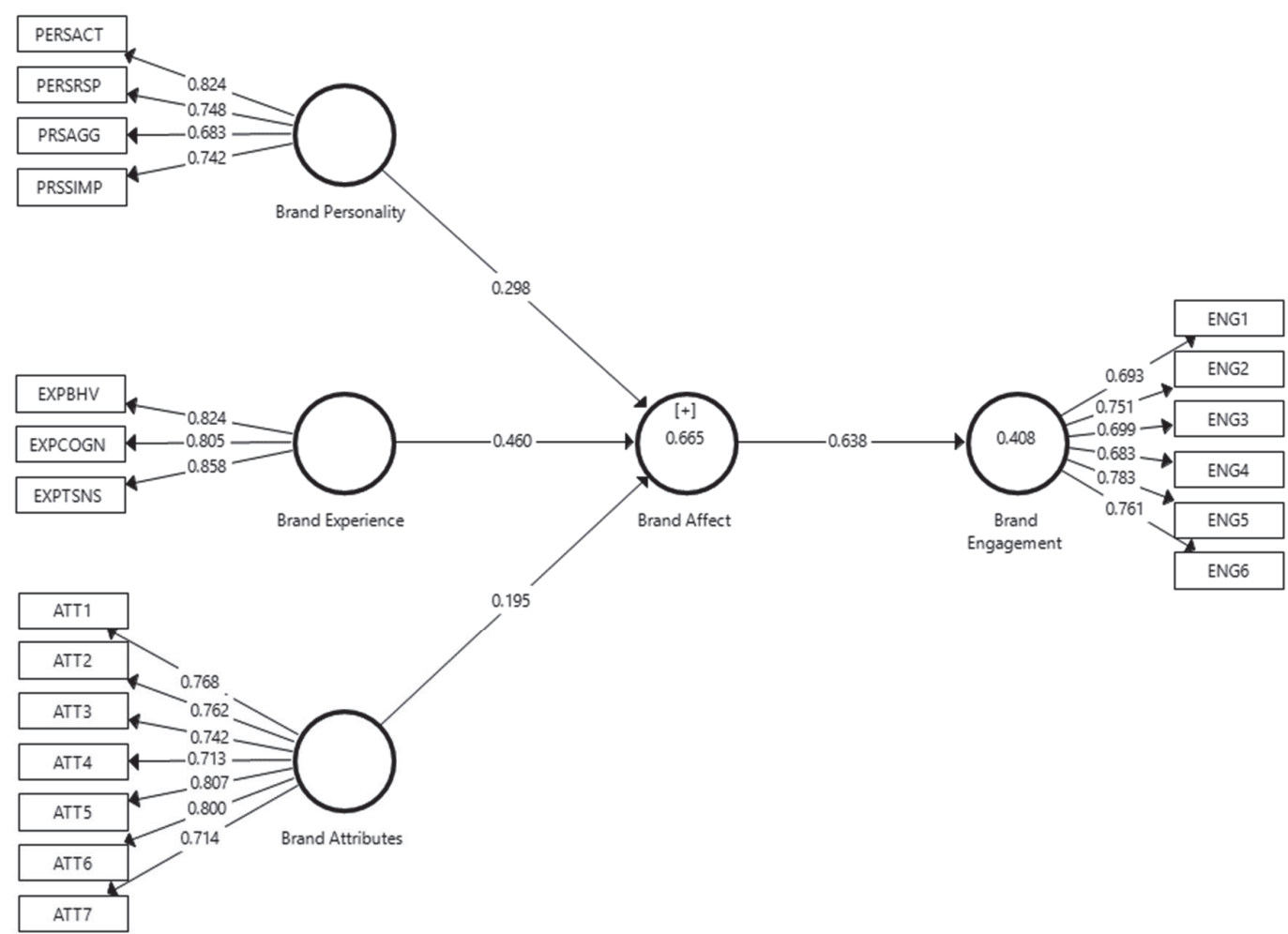

\subsection{Structural model assessment}

In Figure 3, each arrow represents the hypothesized relationships between constructs. The structural model's assessment revealed that Hypothesis 1 on brand personality's influence on brand affect was supported ( $\beta=0.298, t=7.07$, $P$ $=0.000)$; Hypothesis 2 concerning brand experience's influence on brand affect was supported ( $\beta=0.460, t=12.55, P=0.000)$; and Hypothesis 3 on brand attributes' influence on brand affect was also supported $(\beta=0.195, t=4.385, P=0.000)$. Moreover, Hypothesis 4, brand affect's influence on brand engagement, also emerged significant in the results $(\beta=0.638, t=16.830, P=0.000)$. The bootstrapping method was applied for hypotheses 5, 6, and 7, as advised by Hayes and Preacher (2010). The results supported the mediation role of brand affect between brand engagement and brand personality $(\beta=0.190, t=6.359, P=0.000)$, brand experience $(\beta=0.293, t=9.937, P=0.000)$, and brand attributes $(\beta=0.124, t=4.247, P=0.000)$. 
FIGURE 3: Structural model with mediator

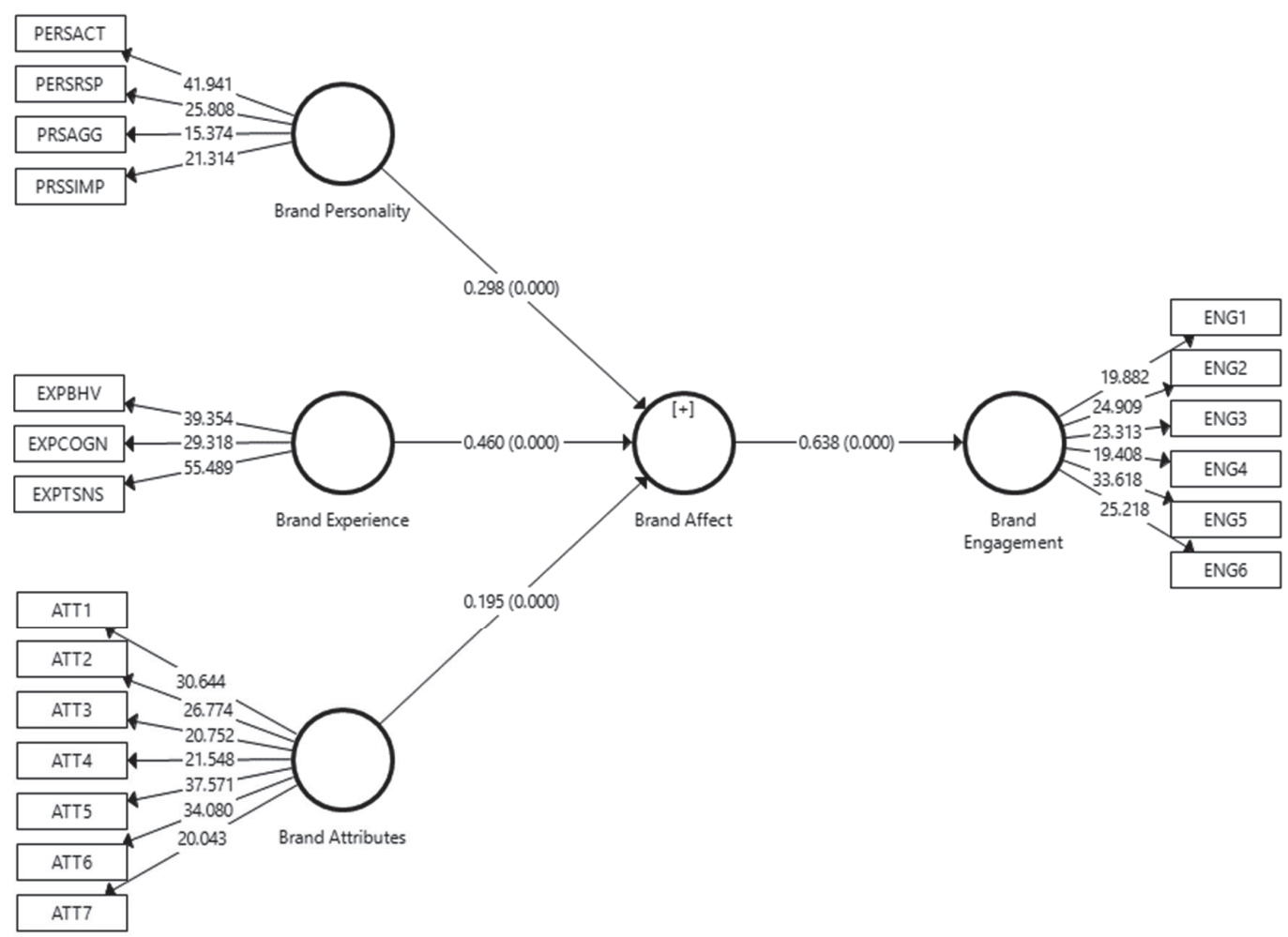

The coefficient of variation $\left(R^{2}\right)$ explains the variation in an endogenous variable (mediator and dependent variables) by an exogenous variable (independent). Accordingly, 66.5\% $\left(R^{2}=0.665\right)$ of brand affect is explained by brand personality, brand experience, and brand attributes. It indicates that $R^{2}$ for brand affect is between moderate and substantial (Henseler, Ringle \& Sinkovics, 2009). In contrast, brand affect explained $40.8 \%\left(R^{2}=0.408\right)$ of brand engagement, placing it between weak and moderate (Henseler et al., 2009). Moreover, the effect size ( $\left.f^{2}\right)$ was also measured to determine the independent contribution of each exogenous variable $\left(R^{2}\right)$ to the endogenous variable. For brand affect, brand attributes displayed $f^{2}=0.056$, brand experi- ence displayed $\mathrm{f}^{2}=0.370$, and brand personality demonstrated $f^{2}=0.153$.

Lastly, predictive relevance $\left(\mathrm{Q}^{2}\right)$ of the research framework was examined using the blindfolding procedure in SmartPLS. Q2 explains if the role of exogenous variables is significant in predicting the endogenous variables in PLS-SEM (Hair et al., 2014). Any $Q^{2}$ value > 0 denotes a substantial predictive relevance of the constructs in a research model (Henseler et al., 2009). As shown in Figure 4, the cross-validated redundancy values pf 0.392 for brand affect and 0.201 for brand engagement show the predictive power of brand personality, brand experience, and brand attributes for brand affect and the predictive power of brand affect for brand engagement, respectively. 


\section{FIGURE 4: Blindfolding results}

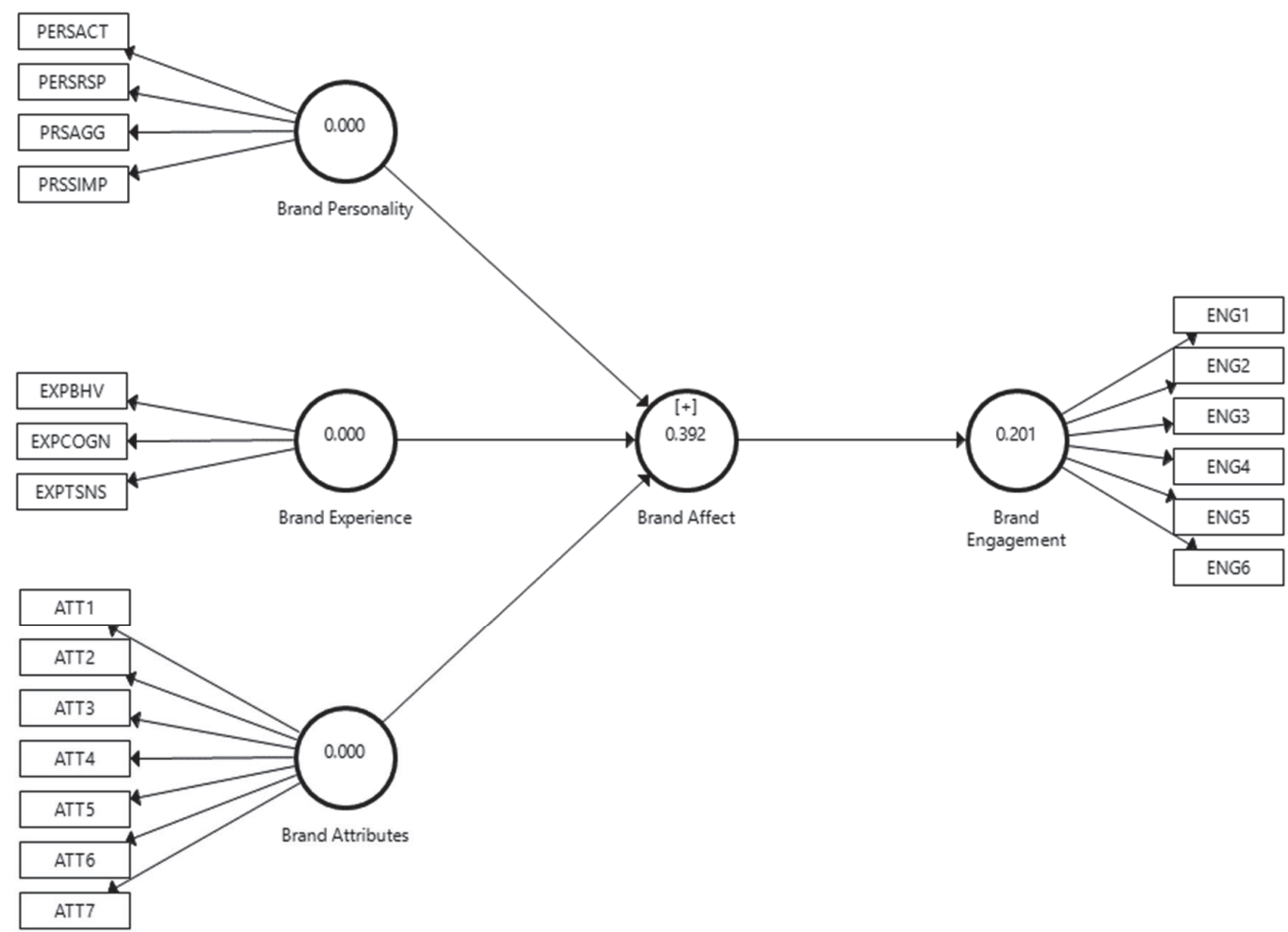

\section{CONCLUSION}

This study focuses on brand engagement and its antecedents in the context of automobile customers in Pakistan. The growing market share of the imported reconditioned automobile brands in the country is a widely acknowledged phenomenon and remains predominantly un-investigated. In line with the CBBE model by Keller (2001, 2016) and the related literature, the influence of brand personality, brand experience, brand attributes, and brand effect on brand engagement (declaration of loyalty) was assessed. An analysis of customers' responses revealed that brand equity drivers - brand personality, brand experience, brand attributes, and brand affect - significantly explain brand engagement behavior through the mediating influence of brand affect.

The study makes contributions to CBBE and relationship marketing theories by filling various gaps in the literature related to brand engagement and its antecedents. It is one of the early studies that provide theoretical and empirical support for linking brand personality, brand experience, brand attributes, and brand affect as the antecedents of brand engagement, in line with the CBBE. Brand engagement also reflects the "close in-sync" relationship between customers and brands. Corroborating this, relationship marketing explains that customers respond to the marketing activities of businesses that provide benefits to customers. This indicates that customers resort to volunteer WOM, referrals, and participating in brand-related activities beyond purchasing and consuming process. Customers' response to brands is the result of customers' perceived value of brands (Blackwell, Szeinbach, Barnes, Garner \& Bush, 1999), which leads to a long-term customer-brand relationship such as brand engagement (Bowden, 2009). The perceived value reflects the benefits 
that brands offer to customers, essentially functioning as core relational factors that lead to a long-term customer-brand relationship and brand engagement behavior (Bowden, 2009). Therefore, this study also aligns brand engagement behavior with the relationship marketing theory by providing empirical evidence of the perceived value implicit in brand personality, brand experience, brand attributes, and brand affect as the antecedents of brand engagement behavior. Especially, the empirical findings of the study enhanced the role of brand affect as a mediator and an antecedent in the CBBE and relationship marketing in relation to brand engagement behavior, which is largely neglected in extant literature. The findings also provide managerial implications for brand engagement behavior as a measure of enduring brand loyalty amongst automobile customers and the drivers to create brand engagement. Specifically, brand experience, brand attributes, and brand affect are the major factors that drive the decisions related to automobile purchases in Pakistan. Additionally, automobile customers in Pakistan prefer the vehicles that display pleasant and desirable brand personality. Thus, the SKDs can leverage brand engagement behavior by designing brands and marketing programs that emphasize brand experience, brand personali- ty, brand attributes, and brand affect. Such marketing programs are potentially instrumental in alleviating the competitive pressures faced by SKDs from the imported automobile brands.

With a $40.7 \%$ variation in brand engagement through brand affect, it is logical to expect that more than one mediator may explain the relationship between personality, experience, attributes, and engagement. Besides, other antecedents may be tested in future studies to expand on the focus of this study, which was limited to three antecedents and one mediating variable. As the research design of this study is cross-sectional, it is recommended for future studies to test the research framework of this study using a longitudinal research design to compare the results. Lastly, as the context of this study is the automobile market of Pakistan, the results may not be generalized to other parts of the world or should at least be referred to judiciously by researchers and marketers in terms of the context. For this, future research studies are recommended to test the research framework of the study in other countries and draw similarities and differences in the results. It is also recommended to test the research framework for product categories other than automobiles to enrich the contextual theory.

\section{References}

1. Aaker, D. A. (1991). Managing brand equity: Capitalizing on the value of a brand name. New York, NY: Free Press.

2. Abbas, G. (2018). Car assemblers come under fire for price increases, low standards, and cartelisation. Retrieved from https://profit.pakistantoday.com.pk/2018/04/12/car-assemblers-comeunder-fire-for-price-increases-low-standards-and-cartelisation/

3. Adetunji, R. R., Rashid, S. M., \& Ishak, S. M. (2018). Social media marketing communication and consumer-based brand equity: An account of automotive brands in Malaysia. Jurnal Komunikasi, Malaysian Journal of Communication, 34(1), 1-19.

4. Agence France-Presse (2015). Pakistan's Japanese-dominated car market poised for new entrants. Retrieved from https://tribune.com.pk/story/930867/pakistans-japanese-dominated-car-market-poised-for-new-entrants/

5. Aguilar, A. G., Guillén, M. J. Y., \& Roman, N. V. (2016). Destination brand personality: An application to Spanish tourism. International Journal of Tourism Research, 18(3), 210-219.

6. Albert, N., \& Merunka, D. (2013). The role of brand love in consumer-brand relationships. Journal of Consumer Marketing, 30(3), 258-266. 
7. Algesheimer, R., Dholakia, U. M., \& Herrmann, A. (2005). The Social influence of brand community: Evidence from European car clubs. Journal of Marketing, 69(3), 19-34.

8. Alloway, T. P., \& Alloway, R. G. (2012). The impact of engagement with social networking sites (SNSs) on cognitive skills. Computers in Human Behavior, 28(5), 1748-1754.

9. Amir, A., \& Asad, M. (2018). Consumer' s purchase intentions towards automobiles in Pakistan. Open Journal of Business and Management, 6, 202-213.

10. Ashley, C., Noble, S. M., Donthu, N., \& Lemon, K. N. (2011). Why customers won't relate: Obstacles to relationship marketing engagement. Journal of Business Research, 64(7), 749-756.

11. Aslam, W., Ham, M., \& Farhat, K. (2018). Influencing factors of brand perception on consumers' repurchase intention: An examination of online apparel shopping. Management: Journal of Contemporary Management Issues, 23(2), 87-102.

12. Azoulay, A., \& Kapferer, J-N. (2003). Do brand personality scales really measure brand personality?. Journal of Brand Management, 11(2), 143-155.

13. Bairrada, C. M., Coelho, A., \& Lizanets, V. (2018). The impact of brand personality on consumer behavior: the role of brand love. Journal of Fashion Marketing and Management: An International Journal, 23(1), 30-47.

14. Becker, J-M., Klein, K., \& Wetzels, M. (2012). Hierarchical latent variable models in PLS-SEM: Guidelines for using reflective-formative type models. Long Range Planning, 45(5/6), 359-394.

15. Bennur, S., \& Jin, B. (2016). The mediating role of brand trust and affect in clothing brand loyalty formation: A cross-cultural examination of U.S. and India. The Journal of the Textile Institute, 108(1), $1-9$.

16. Bento, M., Martinez, L. M., \& Martinez, L. F. (2018). Brand engagement and search for brands on social media: Comparing Generations $X$ and $Y$ in Portugal. Journal of Retailing and Consumer Services, 43, 234-241.

17. Bergkvist, L., \& Bech-Larsen, T. (2010). Two studies of consequences and actionable antecedents of brand love. Journal of Brand Management, 17(7), 504-518.

18. Bernhart, D. W., Grosse-Kleimann, P., \& Hoffmann, D. M. (2011). Automotive landscape 2025. Automotive Competence Center Client Magazine, (Automotive Insights), 12-17.

19. Blackwell, S. A., Szeinbach, S. L., Barnes, J. H., Garner, D. W., \& Bush, V. (1999). The antecedents of customer loyalty. Journal of Service Research, 1(4), 362-375.

20. Bowden, J. (2009). Customer engagement: A framework for assessing customer-brand relationships: The case of the restaurant industry. Journal of Hospitality and Leisure Marketing, 18(6), 574596.

21. Brakus, J. J., Schmitt, B. H., \& Zarantonello, L. (2009). Brand experience: What is it? How is it measured? Does it affect loyalty?. Journal of Marketing, 73(3), 52-68.

22. Brodie, R. J., Hollebeek, L. D., Jurić, B., \& Ilić, A. (2011). Customer engagement: Conceptual domain, fundamental propositions, and implications for research. Journal of Service Research, 14(3), 252271.

23. Brunello, A. (2015). Brand equity in premium car market. International Journal of Communication Research, 5(2), 128-135.

24. Byrne, B. M. (2016). Structural Equation Modelling with AMOS: Basic Concepts, Applications, and Programming. New York, NY: Routledge

25. Calder, B. J., Malthouse, E. C., \& Schaedel, U. (2009). An experimental study of the relationship between online engagement and advertising effectiveness. Journal of Interactive Marketing, 23(4), 321-331.

26. Candi, M., Jae, H., Makarem, S., \& Mohan, M. (2017). Consumer responses to functional, aesthetic and symbolic product design in online reviews. Journal of Business Research, 81, 31-39. 
27. Chan, T. K. H., Zheng, X., Cheung, C. M. K., Lee, M. K. O., \& Lee, Z. W. Y. (2014). Antecedents and consequences of customer engagement in online brand communities. Journal of Marketing Analytics, 2(2), 81-97.

28. Chaudhuri, A., \& Holbrook, M. (2001). The chain of effects from brand trust and brand affect to brand performance: The role of brand loyalty. Journal of Marketing, 65(2), 81-93.

29. Chaudhuri, A., \& Holbrook, M. B. (2002). Product-class effects on brand commitment and brand outcomes: The role of brand trust and brand affect. Journal of Brand Management, 10(1), 33-58.

30. Cheah, J-H., Ting, H., Ramayah, T., Memon, M. A., Cham, T-H., \& Ciavolino, E. (2018). A comparison of five reflective -formative estimation approaches: Reconsideration and recommendations for tourism research. Quality \& Quantity, 53(3), 1421-1458.

31. Chieng, F. Y. \& Lee, G. C. (2011). Customer-based brand equity: A literature review. Journal of Arts Science \& Commerce, 2(1), 33-42.

32. Chitturi, R., Raghunathan, R., \& Mahajan, V. (2007). Form versus function: How the intensities of specific emotions evoked in functional versus hedonic trade-offs mediate product preferences. Journal of Marketing Research, 44(4), 702-714.

33. Dessart, L., Veloutsou, C., \& Morgan-Thomas, A. (2015). Consumer engagement in online brand communities: a social media perspective. Journal of Product \& Brand Management, 24(1), 28-42.

34. Edmunds (2018). Loyalty Report 2018. Santa Monica, CA: Edmunds Press.

35. Edwards, J., Jackson, H. J., \& Pattison, P. E. (2002). Emotion recognition via facial expression and affective prosody in schizophrenia: a methodological review. Clinical psychology review, 22(6), 789-832.

36. Farhat, K., Mokhtar, S., \& Salleh, S. (2020a). Linking brand engagement to customer-based brand equity and role of brand experience, brand personality, and brand affect: A case of automobile market of Pakistan. Management Science Letters, 10(10), 2237-2248.

37. Farhat, K., Mokhtar, S. S. M., \& Salleh, S. B. M. (2020b). Role of brand experience and brand affect in creating brand engagement: a case of higher education institutions (HEls). Journal of Marketing for Higher Education, 1-29.

38. Fernandes, T., \& Esteves, F. (2016). Customer engagement and loyalty: A comparative study between service contexts. Services Marketing Quarterly, 37(2), 125-139.

39. Flop gear. (2015). Retrieved from https://www.economist.com/asia/2015/05/09/flop-gear

40. Franzak, F., Makarem, S., \& Jae, H. (2014). Design benefits, emotional responses, and brand engagement. Journal of Product \& Brand Management, 23(1), 16-23.

41. Füller, J., Matzler, K., \& Hoppe, M. (2008). Brand community members as a source of innovation. Journal of Product Innovation Management, 25(6), 608-619.

42. Gerrits, M., Zhang, D., Klotz, A., Xu, L., \& Xie, A. (2014). The battle for automotive brand loyalty in China. Retrieved from http://image-src.bcg.com/Images/The_Battle_for_Automotive_Brand_ Loyalty_in_China_Sep_2014_tcm96-74435.pdf

43. Geuens, M., Weijters, B., \& De Wulf, K. (2009). A new measure of brand personality. International Journal of Research in Marketing, 26(2), 97-107.

44. Gold, A. H., Malhotra, A., \& Segars, A. H. (2001). Knowledge management: An organizational capabilities perspective. Journal of Management Information Systems, 18(1), 185-214.

45. Hair, J. F., Hult, G. T. M., Ringle, C. M., \& Sarstedt, M. (2014). A primer on partial least squares structural equation modeling (PLS-SEM). New Jersey, NJ: SAGE Publications.

46. Hair, J. F., Risher, J. J., Sarstedt, M., \& Ringle, C. M. (2019). When to use and how to report the results of PLS-SEM. European Business Review, 31(1), 2-24.

47. Hair, J. F., Sarstedt, M., Ringle, C. M., \& Mena, J. A. (2011). An assessment of the use of partial least squares structural equation modeling in marketing research. Journal of the Academy of Marketing Science, 40(3), 414-433. 
48. Halaszovich, T., \& Nel, J. (2017). Customer-brand engagement and Facebook fan-page "Like"-intention. Journal of Product \& Brand Management, 26(2), 120-134.

49. Hanan, A. (2016). A look into the enigmatic buying trend of Pakistan's auto consumers. Retrieved from https://www.pakwheels.com/blog/car-buying-habits-pakistanis/

50. Hayes, A. F., \& Preacher, K. J. (2010). Quantifying and testing indirect effects in simple mediation models when the constituent paths are nonlinear. Multivariate Behavioral Research, 45(4), 627660.

51. Helander, M. G., Khalid, H. M., Lim, T. Y., Peng, H., \& Yang, X. (2013). Emotional needs of car buyers and emotional intent of car designers. Theoretical Issues in Ergonomics Science, 14(5), 455-474.

52. Henseler, J., Ringle, C., \& Sinkovics, R. (2009). The use of partial least squares path modeling in international marketing. Advances in International Marketing, 20, 277-319.

53. Holbrook, M. B., \& Hirschman, E. C. (1982). The experiential aspects of consumption: Consumer fantasies, feelings, and fun. Journal of Consumer Research, 9(2), 132-140.

54. Huang, C. C. (2017). The impacts of brand experiences on brand loyalty: mediators of brand love and trust. Management Decision, 55(5), 915-934.

55. Javornik, A., \& Mandelli, A. (2012). Behavioral perspectives of customer engagement: An exploratory study of customer engagement with three Swiss FMCG brands. Journal of Database Marketing and Customer Strategy Management, 19(4), 300-310.

56. Junaid, M., Hou, F., Hussain, K., \& Kirmani, A. A. (2019). Brand love: The emotional bridge between experience and engagement, generation - M perspective. Journal of Product \& Brand Management, 28(2), 200-215.

57. Keller, K. L. (2001). Building customer-based brand equity: A blueprint for creating strong brands building customer-based brand equity. Journal of Marketing Communications, 15(2/3), 139-155.

58. Keller, K. L. (2003). Understanding brands, branding and brand equity. Interactive Marketing, 5(1), $7-20$.

59. Keller, K. L. (2013). Strategic brand management. Harlow: Pearson Education.

60. Keller, K. L. (2016). Reflections on customer-based brand equity: perspectives, progress, and priorities. AMS Review, 6(1/2), 1-16.

61. Khan, A. S. (2017). Used car imports claim bigger chunk in auto sales. Retrieved from https:// www.dawn.com/news/1309553

62. Khong, K. W., \& Ong, F. S. (2014). Shopper perception and loyalty: A stochastic approach to modelling shopping mall behaviour. International Journal of Retail \& Distribution Management, 42(7), 626-642.

63. Kim, R. B., \& Zhao, M. (2014). Chinese consumers' brand loyalty for consumer products: Importance of brand personality as major antecedent of brand loyalty. Asian Academy of Management Journal, 19(1), 1-15.

64. Krejcie, R. V, \& Morgan, D. W. (1970). Determining sample size for research activities. Educational and Psychological Measurement, 30(3), 607-610.

65. Kumar, A., Lee, H.-J., \& Kim, Y.-K. (2009). Indian consumers purchase intention toward a United States versus local brand. Journal of Business Research, 62(5), 521-527.

66. Kumar, V., Aksoy, L., Donkers, B., Venkatesan, R., Wiesel, T., \& Tillmanns, S. (2010). Undervalued or overvalued customers: Capturing total customer engagement value. Journal of Service Research, 13(3), 297-310.

67. Laghari, A. (2018). Pakistanis imported 65,723 used cars in 2017. Retrieved from https://www. pakwheels.com/blog/65723-used-cars-imported-2017/

68. Lassar, W., Mittal, B., \& Sharma, A. (1995). Measuring customer-based brand equity. Journal of consumer marketing, 12(4), 11-19 
69. Lee, Y-K., Back, K-J., \& Kim, J-Y. (2009). Family restaurant brand personality and its impact on customers' emotion, satisfaction, and brand loyalty. Journal of Hospitality \& Tourism Research, 33(3), 305-328.

70. Lemon, K. N., \& Verhoef, P. C. (2016). Understanding customer experience throughout the customer journey. Journal of Marketing, 80(6), 69-96.

71. Liao, L. X., Corsi, A. M., Chrysochou, P., \& Lockshin, L. (2015). Emotional responses towards food packaging: A joint application of self-report and physiological measures of emotion. Food Quality and Preference, 42, 48-55.

72. Lin, M. Q., \& Lee, B. C. (2012). The influence of website environment on brand loyalty: Brand trust and brand affect as mediators. International Journal of Electronic Business Management, 10(4), 308-321.

73. Loureiro, S. M. C., Pires, A. R., \& Kaufmann, H. R. (2015). Creating value for customers through engagement and participation in brand communities. International Journal of Business Performance Management, 16(2/3), 114-132.

74. Lyu, J., Mao, Z., \& Hu, L. (2018). Cruise experience and its contribution to subjective well-being: A case of Chinese tourists. International Journal of Tourism Research, 20(2), 225-235.

75. Malhotra, N. K., \& Dash, S. (2016). Marketing research: An applied orientation. Delhi: Pearson.

76. Mattila, A. S., \& Enz, C. A. (2002). The role of emotions in service encounters. Journal of Service Research, 4(4), 268-277.

77. Matzler, K., Pichler, E. A., \& Hemetsberger, A. (2007). Who is spreading the word? The positive influence of extraversion on consumer passion and brand evangelism. Marketing Theory and Applications, 18(1), 25-32.

78. Mehmood, F. (2015). Why people buy used imported cars instead of new local cars. Retrieved from https://www.automark.pk/people-buy-used-imported-cars-instead-new-local-cars/

79. Metrix, M. (2002). Evoking emotion. Cornell Hotel and Restaurant Administration Quarterly, 18, 39-46.

80. Nielsen Global. (2014). Secure tomorrow's car buyers today. Retrieved from https://www.nielsen.com/content/dam/corporate/mx/reports/2014/Nielsen\%20Global\%20Automotive\%20Demand\%20Report\%20April\%202014.pdf

81. Noble, C. H., \& Kumar, M. (2010). Exploring the appeal of product design: A grounded, value-based model of key design elements and relationships. Journal of Product Innovation Management, 27(5), 640-657.

82. Orzan, G., Platon, O. E., Stefanescu, C. D., \& Orzan, M. (2016). Conceptual model regarding the influence of social media marketing communication on brand trust, brand affect and brand loyalty. Economic Computation and Economic Cybernetics Studies and Research, 50(1), 141-156.

83. Pansari, A., \& Kumar, V. (2017). Customer engagement: the construct, antecedents, and consequences. Journal of the Academy of Marketing Science, 45(3), 294-311.

84. Park, J. H., \& Park, J. W. (2015). The effects of experience in the A380 duty free showcase on customer behaviors. Journal of Air Transport Management, 47, 135-141.

85. Pham, M. T. (2004). The logic of feeling. Journal of Consumer Psychology, 14(4), 360-369.

86. Pitta, D. A., \& Katsanis, L. P. (1995). Understanding brand equity for successful brand extension. Journal of Consumer Marketing, 12(4), 51-64.

87. Podsakoff, P. M., \& Organ, D. W. (1986). Self-reports in organizational research problems and prospects. Journal of Management, 12(4), 531-544.

88. Pullman, M. E., \& Gross, M. A. (2004). Ability of experience design elements to elicit emotions and loyalty behaviors. Decision Sciences, 35(3), 551-578.

89. Punyatoya, P. (2011). How brand personality affects products with different involvement levels? European Journal of Business and Management, 3(2), 104-107.

90. Ramayah, T. W. C., Chow, J. W., \& Chyaw, J. B. (2011). Network collaboration and performance in the tourism sector. Service Business, 5(4), 411-428. 
91. Razzaq, Z., Yousaf, S., \& Hong, Z. (2017). The moderating impact of emotions on customer equity drivers and loyalty intentions. Asia Pacific Journal of Marketing and Logistics, 29(2), 239-264.

92. Reichheld, F. F. (2003). The one number you need to grow. Harvard Business Review, 81(12), 46-54.

93. Ringle, C. M., Sarstedt, M., \& Straub, C. (2012). Editors comments: A critical look at the use of PLSSEM in MIS Quarterly. MIS Quarterly, 36(1), 12-19.

94. Roy, P., Khandeparkar, K., \& Motiani, M. (2016). A lovable personality: The effect of brand personality on brand love. Journal of Brand Management, 23(5), 97-113.

95. Salkind, N. J. (2012). Exploring Research. Upper Saddle River, New Jersey, NJ: Pearson Education.

96. Samala, N., \& Singh, S. (2019). Millennial's engagement with fashion brands: A moderated-mediation model of brand engagement with self-concept, involvement and knowledge. Journal of Fashion Marketing and Management, 23(1), 2-16.

97. Sarstedt, M., Hair, J. F., Cheah, J-H., Becker, J-M., \& Ringle, C. M. (2019). How to specify, estimate, and validate higher-order constructs in PLS-SEM. Australasian Marketing Journal, 27(3), 197-211.

98. Sashi, C. M. (2012). Customer engagement, buyer-seller relationships, and social media. Management Decision, 50(2), 253-272.

99. Sheng, M. L., \&Teo, T. S. (2012). Product attributes and brand equity in the mobile domain: The mediating role of customer experience. International Journal of Information Management, 32(2), 139-146.

100. Sierra, V., Iglesias, O., Markovic, S., \& Singh, J. J. (2015). Does ethical image build equity in corporate services brands? The influence of customer perceived ethicality on affect, perceived quality, and equity. Journal of Business Ethics, 144(3), 661-676.

101. Skier, P. (2017). Shifting gears: Why the automotive industry needs to accelerate customer-centricity. Retrieved from https://www.visioncritical.com/customer-centricity-automotive-industry/

102. Song, Y., Qin, Z., \& Yuan, Q. (2019). The impact of eco-label on the young Chinese generation: The mediation role of environmental awareness and product attributes in green purchase. Sustainability, 11(4), 973-984.

103. Sudman, S. (1980). Improving the quality of shopping center sampling. Journal of Marketing Research, 17(4), 423-429.

104. Sudman, S., \& Blair, E. (1999). Sampling in the twenty-first century. Journal of the Academy of Marketing Science, 27(2), 269-277.

105. Sung, Y., \& Kim, J. (2010). Effects of brand personality on brand trust and brand affect. Psychology \& Marketing, 27(7), 693-661.

106. The Heart of the Issue: Emotional motivators rev up automotive purchase intentions around the world. (2014). Retrieved from http://www.nielsen.com/us/en/insights/news/2014/the-heart-ofthe-issue-emotional-motivators-rev-up-automotive-purchase-intentions-around-the-world.html

107. van Doorn, J., Lemon, K. N., Mittal, V., Nass, S., Pick, D., Pirner, P., \& Verhoef, P. C. (2010). Customer engagement behavior: Theoretical foundations and research directions. Journal of Service Research, 13(3), 253-266.

108. Verleye, K., Gemmel, P., \& Rangarajan, D. (2014). Managing engagement behaviors in a network of customers and stakeholders: Evidence from the nursing home sector. Journal of Service Research, $17(1), 68-84$

109. Vivek, S. D., Beatty, S. E., \& Morgan, R. M. (2012). Customer engagement: Exploring customer relationships beyond purchase. The Journal of Marketing Theory and Practice, 20(2), 122-146.

110. Wakefield, K. L., \& Blodgett, J. G. (1999). Customer response to intangible and tangible service factors. Psychology and Marketing, 16(1), 51-68.

111. Xie, Y., Batra, R., \& Peng, S. (2015). An extended model of preference formation between global and local brands: The roles of identity expressiveness, trust, and affect. Journal of International Marketing, 23(1), 50-71. 
112. Yanfei, C., \& Yafeng, Z. (2012, October). Theoretical model analysis of relationship marketing. In 2012 International Conference on Information Management, Innovation Management and Industrial Engineering (1, 534-537). IEEE.

113. Yasin, M., Porcu, L., Liébana-Cabanillas, F., \& Cabanillas, L. (2019). The effect of brand experience on customers' engagement Behavior within the context of online brand communities: The impact on intention to forward online company-generated content. Sustainability, 11(17), 46-49.

114. Yoshida, M., Gordon, B. S., Nakazawa, M., Shibuya, S., \& Fujiwara, N. (2018). Bridging the gap between social media and behavioral brand loyalty. Electronic Commerce Research and Applications, 28, 208-218.

115. Zia, N. U., \& Sohail, M. (2016). Factors effecting consumer brand preferences in automobile Industry. Singaporean Journal of Business Economics and Management Studies, 5(3), 55-65.

\section{Appendix A}

Cross loadings - 2nd stage measurement model

\begin{tabular}{|c|c|c|c|c|c|}
\hline & Affect & Attributes & Experience & Personality & Engagement \\
\hline AFF1 & 0.751 & 0.499 & 0.470 & 0.530 & 0.512 \\
\hline AFF2 & 0.830 & 0.519 & 0.587 & 0.535 & 0.527 \\
\hline AFF3 & 0.776 & 0.483 & 0.571 & 0.497 & 0.470 \\
\hline AFF4 & 0.845 & 0.602 & 0.641 & 0.563 & 0.502 \\
\hline AFF5 & 0.764 & 0.532 & 0.643 & 0.497 & 0.523 \\
\hline ATT1 & 0.586 & 0.768 & 0.516 & 0.531 & 0.438 \\
\hline ATT2 & 0.485 & 0.762 & 0.424 & 0.400 & 0.376 \\
\hline ATT3 & 0.471 & 0.742 & 0.393 & 0.482 & 0.287 \\
\hline ATT4 & 0.503 & 0.713 & 0.425 & 0.539 & 0.378 \\
\hline ATT5 & 0.530 & 0.807 & 0.550 & 0.475 & 0.460 \\
\hline ATT6 & 0.515 & 0.800 & 0.524 & 0.492 & 0.446 \\
\hline ATT7 & 0.419 & 0.714 & 0.434 & 0.385 & 0.346 \\
\hline ENG1 & 0.442 & 0.377 & 0.355 & 0.382 & 0.693 \\
\hline ENG2 & 0.483 & 0.391 & 0.389 & 0.417 & 0.751 \\
\hline ENG3 & 0.431 & 0.351 & 0.419 & 0.336 & 0.699 \\
\hline ENG4 & 0.41 & 0.334 & 0.388 & 0.393 & 0.683 \\
\hline ENG5 & 0.513 & 0.423 & 0.475 & 0.434 & 0.783 \\
\hline ENG6 & 0.505 & 0.386 & 0.404 & 0.447 & 0.761 \\
\hline EXPBHV & 0.666 & 0.584 & 0.824 & 0.551 & 0.500 \\
\hline EXPCOGN & 0.534 & 0.404 & 0.805 & 0.311 & 0.395 \\
\hline EXPTSNS & 0.618 & 0.533 & 0.858 & 0.416 & 0.478 \\
\hline PERSACT & 0.604 & 0.596 & 0.490 & 0.824 & 0.469 \\
\hline PERSRSP & 0.457 & 0.409 & 0.323 & 0.748 & 0.370 \\
\hline PRSAGG & 0.428 & 0.426 & 0.415 & 0.683 & 0.391 \\
\hline PRSSIMP & 0.470 & 0.421 & 0.327 & 0.742 & 0.422 \\
\hline
\end{tabular}

* AFF= brand affect; ENG = brand engagement; EXPBHV = behavioral experience; EXPCOG = cognitive experience; EXPSNS = sensory experience PERSACT = personality - activity; PERSRSP = personality - responsibility; PERSAGG = personality aggressiveness; PRSSIMP = personality - simplicity 